\begin{tabular}{|l|c|c|c|r|}
\hline $\begin{array}{l}\text { Cuadernos de Investigación Geográfica } \\
\text { Geographical Research Letters }\end{array}$ & 2018 & No $^{\circ} 44(2)$ & pp. 475-502 & $\begin{array}{r}\text { ISSN 0211-6820 } \\
\text { eISSN 1697-9540 }\end{array}$ \\
\hline
\end{tabular}

\title{
WHAT HAVE WE LEARNT ABOUT MEDITERRANEAN CATCHMENT HYDROLOGY? 30 YEARS OBSERVING HYDROLOGICAL PROCESSES IN THE VALLCEBRE RESEARCH CATCHMENTS
}

\author{
P. LLORENS*, F. GALLART, C. CAYUELA, M. ROIG-PLANASDEMUNT, \\ E. CASELLAS, A.J. MOLINA, M. MORENO DE LAS HERAS, \\ G. BERTRAN, E.SÁNCHEZ-COSTA, J. LATRON
}

Institute of Environmental Assessment and Water Research (IDAEA-CSIC), Jordi Girona, 18-26, 08034 Barcelona, Spain.

\begin{abstract}
This paper presents the main results obtained from the study of hydrological processes in the Vallcebre Research Catchments since 1988. Distributed hydrometric measurements, environmental tracers and hydrological modelling were used to understand Mediterranean catchment behaviour and to provide new data to help assess the global change effects on these catchments' water resources. Thirty years of hydrological processes observation in the Vallcebre Research Catchments have increased understanding not only of their hydrological response, but also of the main hydrological and erosion processes characteristic of Mediterranean mountain catchments. This paper briefly summarises the main results obtained since 1988 on ecohydrological processes, hydrological response, runoff generation processes, erosion and sediment transport. Some of the main findings from this research are (i) the importance of temporal variability in precipitation to determine the hydrological processes; (ii) the paramount role played by forest cover in reducing soil water content; (iii) the marked influence of antecedent wetness conditions on runoff generation that determine different runoff responses; ( $v$ ) the dominant contribution of pre-existing water during floods; (vi) the importance of freezing-thawing processes in badland areas on erosion and the role of summer convective storms in controlling sediment transport.
\end{abstract}

¿Qué hemos aprendido sobre la hidrología de cuencas Mediterráneas? 30 años observando los procesos hidrológicos en las cuencas de investigación de Vallcebre

RESUMEN. Este trabajo presenta los principales resultados sobre el estudio de los procesos hidrológicos obtenidos en las cuencas de investigación de Vallcebre desde 1988. Se han utilizado aproximaciones metodológicas complementarias, tales como mediciones hidrométricas distribuidas, trazadores ambientales y modelización hidrológica con la finalidad de mejorar la comprensión de la respuesta de las cuencas mediterráneas y proporcionar nuevos conocimientos válidos para evaluar los efectos 
de cambio global en los recursos hídricos de estas cuencas. Treinta años de observaciones de los procesos hidrológicos en las cuencas de investigación de Vallcebre han permitido comprender no sólo su respuesta hidrológica, sino también los principales procesos hidrológicos y de erosión propios de las cuencas mediterráneas. Este artículo resume los principales resultados obtenidos desde 1988 sobre los procesos ecohidrológicos, la respuesta hidrológica, los procesos de generación de escorrentía, la erosión y el transporte de sedimentos. Algunos de los principales resultados de estas investigaciones son (i) la crucial importancia de la variabilidad temporal de las precipitaciones en los procesos hidrológicos; (ii) el papel fundamental de la cubierta forestal en la reducción del contenido hídrico del suelo; (iii) la marcada influencia de las condiciones de humedad antecedentes en la generación de escorrentía y su efecto en las diferentes respuestas hidrológicas; v) la contribución dominante de las aguas preexistentes durante las crecidas; vi) la importancia que tienen sobre la erosión los procesos de hielo-deshielo en las áreas de badlands y el papel de las tormentas convectivas de verano en el transporte de sedimentos.

Key words: hydrological processes, environmental tracers, Vallcebre research catchments, Mediterranean mountain area.

Palabras clave: procesos hidrológicos, trazadores ambientales, cuencas de investigación de Vallcebre, área de montaña mediterránea.

Received: 16 October 2017

Accepted: 5 December 2017

*Corresponding author: Pilar Llorens, Institute of Environmental Assessment and Water Research (IDAEA-CSIC), Jordi Girona, 18-26, 08034 Barcelona, Spain. E-mail address: pilar.llorens@idaea.csic.es

\section{Introduction}

The study and modelling of hydrological processes in the Vallcebre research catchments started about 30 years ago with the aim of improving the understanding of hydrological processes that control the seasonality of the response in Mediterranean catchments. The research area was selected in 1988 to analyse the hydrological consequences of land abandonment, as well as the hydrological and sediment yield behaviour of badlands areas. The approach used combines various complementary methodologies, such as distributed hydrometric measurements, environmental tracers and hydrological modelling, and provides new insights into the effects of global change on water resources. This paper briefly summarises the main results obtained since 1988 on the spatio-temporal dynamics of precipitation, rainfall partitioning, forest transpiration and ecohydrological processes, soil water and groundwater dynamics, hydrological response and runoff generation processes, erosion and sediment transport, as well as some results derived from modelling at several spatial and temporal scales.

Our continuous concern for the field study of hydrological processes in the Vallcebre research catchments is our grain of sand to add to recent opinion papers (e.g. Burt and 
McDonnell, 2015) advocating the continuity of field studies in catchment hydrology. This continuity is especially important at a time when it is more efficient to produce papers on modelling than on field studies (Burt and McDonnell, 2015; Beven, 2016). We are indeed convinced that, as indicated by Beven (2016), measurement and fieldwork are unique tools for understanding environmental processes and developing new explanations of how catchments function. We also agree that there is a need not only for short-term experiments or campaigns, sometimes only designed to calibrate and validate hydrological models, but also for long-term data from research catchments to further process understanding, observe trends and test new ideas, methods or instruments (Burt and McDonnell, 2015; Tetzlaff et al., 2017).

\section{Study site}

\subsection{General setting}

The Vallcebre research area is located close to Vallcebre village (Spain), at the headwaters of the Llobregat river, about $100 \mathrm{~km}$ North of Barcelona, in the South-eastern part of the Pyrenees ( $42^{\circ} 12^{\prime} \mathrm{N}$ and $\left.1^{\circ} 49^{\prime} \mathrm{E}\right)$ (Fig. 1). The Llobregat River provides the main water supply for the Barcelona area.

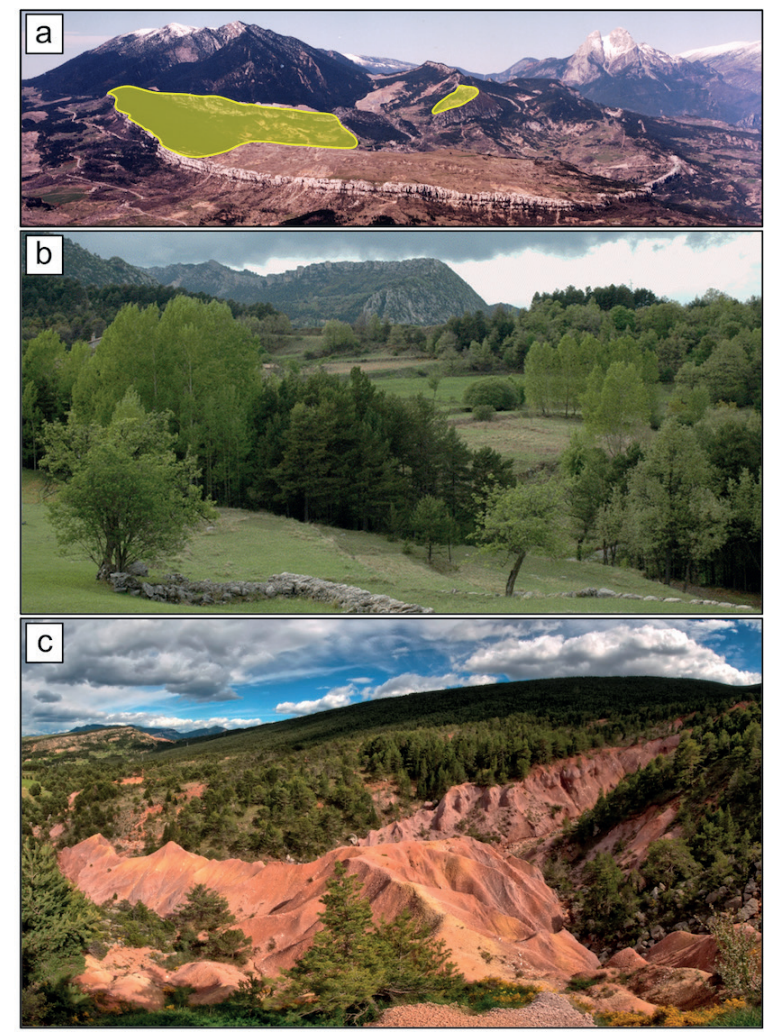

Figure 1. Map of the Vallcebre Research Catchments, showing locations of the currently monitored forest plots and of the main instruments operating in 2016. 
Within the Vallcebre research area, the Surface Hydrology and Erosion group of the IDAEA_CSIC has monitored two clusters of five catchments (Fig. 2a). The main cluster, the Cal Rodó catchment $\left(4.17 \mathrm{Km}^{2}\right)$, has two sub-catchments: Can Vila $\left(0.56 \mathrm{Km}^{2}\right)$ and Ca l'Isard $\left(1.32 \mathrm{~km}^{2}\right)$. The smallest cluster, Cal Parisa $\left(0.32 \mathrm{~km}^{2}\right)$ is formed by two contiguous catchments of similar size. Long-term monitoring of forest plots, covered by Scots pines or by pubescent oaks, are also part of this research facility (Fig. 1).

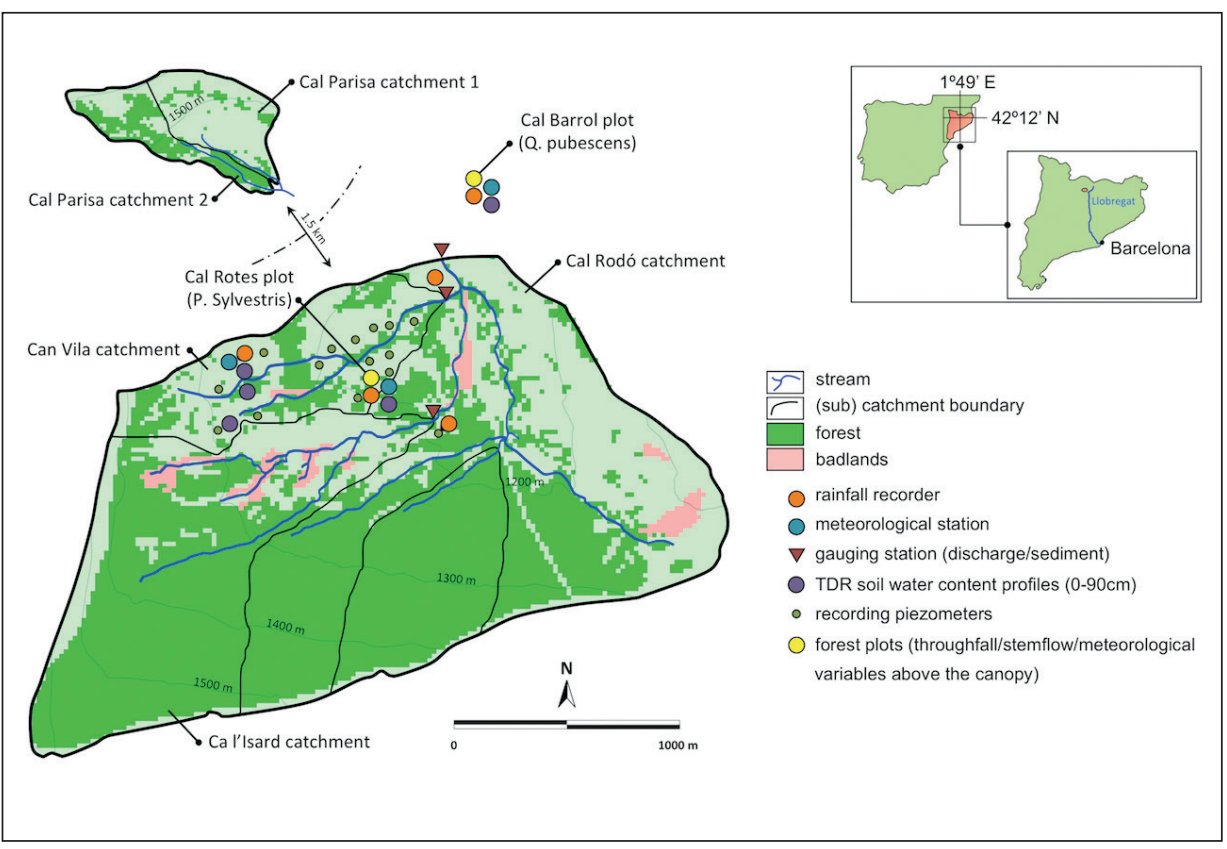

Figure 2. General view of Vallcebre Research Catchments (a). The smaller catchment on the right is the Cal Parisa catchment and the larger one on the left is the Cal Rodó catchment. The catchments are covered by pastures and forest (b) with some small badlands areas (c) close to the stream.

\subsection{Topography}

Within the Vallcebre research area, altitudes range between 1100 and $1700 \mathrm{~m}$ a.s.l. Slopes vary between $10 \%$ and $40 \%$ (mean value $28 \%$ ) and mostly face northeast. The topographical limits of the catchments are well defined, and correspond in over half the Cal Parisa and Cal Rodó catchments to the same limestone bed folded in a near-vertical plane.

Drainage density is relatively low $\left(2.6 \mathrm{~km} \mathrm{~km}^{-2}\right)$ and channels are only fully active during floods. Conversely, during baseflow conditions less than half the total channel length is active. The main channels are 1 to $3 \mathrm{~m}$ wide and are not very deeply incised. The streambeds follow mostly a riffle-pool sequence, with the materials mainly formed 
by coarse alluvium partly cemented by lime coatings. Mobile sediments are mostly fine sands and silt. There are no riparian zones in the catchments.

Before and during the 19th century most of the hillslopes were deforested and terraced for agricultural purposes. The size of the terraces depends greatly on the local gradient, but most of them are 10 to $20 \mathrm{~m}$ wide, often limited by a stone wall up to $2 \mathrm{~m}$ high. The terraced topography covers around half the area. Along with terraces, a network of ditches was also built in order to prevent soil saturation and to convey surface runoff (Llorens et al., 1992; Gallart et al., 1994). However, this artificial drainage network is less extensive than the natural stream, though in some places the differentiation between artificial and natural stream is not straightforward.

\subsection{Vegetation}

Climax vegetation is woodland of pubescent oak (Quercus pubescens) with Scots pine (Pinus sylvestris) on the cooler north-facing aspects. Most of the gentle hillslopes, which were deforested in the past and terraced, are now covered by mesophile grasses with hydrophile patches of Molinia coerulea and are used for either grass harvesting or extensive sheep grazing. Following land abandonment in the sixties, spontaneous forestation by Pinus sylvestris occurred (Poyatos et al., 2003) and forest now covers half the area (Fig. 2b). The remainder of the area is widely covered by pasture and meadows, along with small areas of sparse scrub vegetation and bare soil.

The three pine plots studied (Cal Parisa, Cal Sort and Cal Rotes) are covered by monospecific Pinus sylvestris stands. These plots were selected as representative of patches of pines overgrown in marginal terraced areas that were abandoned in the second half of the 20th century. The plots are rather young stands (the oldest trees are about 70 years old) with scarce understorey (mainly Buxus sempervirens). Stand density varies between 1,189 and 2,400 trees ha $^{-1}$, with mean diameter at breast height (DBH) between 17 and $25 \mathrm{~cm}$. The Quercus pubescens plot (Cal Barrol) is characterized by the presence of other woody species (Prunus avium L., Fraxinus excelsior L.) and a dense understorey (Acer campestre L., Buxus sempervirens L., Prunus spinosa L., Rubus spp. and Rosa Spp.) Stand density is 518 trees ha ${ }^{-1}$ and mean DBH about $20 \mathrm{~cm}$.

\subsection{Geology and soils}

In the South half of the Cal Rodó catchment, bedrock is massive limestone of continental Garumnian facies (Aepler, 1968), with very few conspicuous karstic features. Elsewhere bedrock is formed by red clayey smectite-rich mudrocks. The soft mudstones are prone to landslides and erosion by water, leading to intensely dissected landscapes with poor vegetation cover (badlands) as a result of the combined effects of winter freezing and summer rainstorms (Regüés et al., 1995). Badlands areas (Fig. 2c) occupy less than $3 \%$ of the Cal Rodó catchment area, but play a dominant role in sediment production (Gallart et al., 2005). 
Soil thickness varies greatly, depending on lithology, geomorphology and terracing. Limestone areas are overlain by discontinuous soils less than $40 \mathrm{~cm}$ deep, whereas soils on hillslopes over clayey rocks may reach a depth of $80 \mathrm{~cm}$. Badlands areas have regoliths whose thickness varies throughout the year, but which rarely reach $15 \mathrm{~cm}$. Finally, soil thickness ranges from less than $50 \mathrm{~cm}$ in the inner part of the terraces to more than 2 or $3 \mathrm{~m}$ in their outer part (Latron et al., 2008).

Soils have a silty loam and silty clay loam texture. Bulk density increases with increasing depth, from $0.85 \mathrm{~g} \mathrm{~cm}^{-3}$ in the top layer to $1.65 \mathrm{~g} \mathrm{~cm}^{-3}$ at $50 \mathrm{~cm}$. On the contrary, organic matter decreases with increasing depth from $15.3 \%$ to $0.3 \%$ (Rubio et al., 2008). These characteristics promote high infiltration capacities in the first $20 \mathrm{~cm}$ below the surface (Sole et al., 1992) and the dropping of hydraulic conductivity by several orders of magnitude in the deeper horizons (Haro et al., 1992; Rubio, 2005), inducing the formation of shallow semi-permanent aquifers, despite the high topographic gradients. The arrangement of agricultural terraces also results in the great spatial variability of hydraulic conductivities, which tend to be much higher near the outer edges than in the internal parts. Soil cracking during summer is favoured by smectite clay content and enhances infiltration capacity, whereas soil crusting was only observed on bare badlands surfaces (Regüés et al., 1995).

\section{Field measurements, monitoring and sampling}

In addition to the monitoring of meteorological variables, precipitation, discharge and sediment concentration measured at the catchment outlet for almost 3 decades, several spatially distributed state variables (soil water content and piezometric levels) and fluxes (rainfall partitioning and transpiration) have also been recorded, though for shorter periods. Moreover, since 2011 rainwater, throughfall, stemflow, runoff and several hydrological compartments (soil water, groundwater and vegetation) have been sampled intensively for isotopic determinations. Figure 3 shows some details of the monitoring set-ups (catchment and plot scales) for the measurement and sampling of hydrological variables and fluxes; and Table 1 shows the location of measurement sites and the periods of data recording and sampling.

Data on rainfall partitioning and forest transpiration were obtained at one Scots pine plot located in the Cal Parisa catchment (Cal Parisa plot), two other Scots pine plots located in the Cal Rodó catchment (Cal Sort and Cal Rotes plots) and a Quercus plot located near the Cal Rodó outlet (Cal Barrol plot). Soil water content data on the catchment scale were obtained in a set of TDR profiles at both the Cal Parisa and Can Vila catchments and, on the plot scale, from a densely monitored terrace in the Can Vila catchment. Distributed water table data were obtained mainly from the Can Vila catchment. Main results on hydrological response and runoff generation processes were obtained from the Can Vila catchment. The main reason for selecting this catchment instead of Cal Rodó was that Can Vila is totally watertight. Indeed, the geological setting of the Cal Rodó catchment has raised some questions about its hydrological limits and the issue of its water tightness. By establishing a monthly water balance between the Cal Rodó catchment and the Can Vila sub-catchment, entirely on clayey bedrock, deep 
percolation through the limestone was calculated over a period of 26 months as $21 \%$ of incoming rainfall (Latron, 2003). The ratio between monthly loss through the limestone and precipitation is relatively similar during dry and wet periods and deep percolation has been found to affect essentially baseflow volumes and not stormflow ones. Finally, erosion processes and suspended sediment transport data have been investigated mainly in the Ca l'Isard catchment, where most of the badlands areas are located. Within this catchment, an elementary badlands area of $1200 \mathrm{~m}^{2}(\mathrm{El}$ Carot) was also instrumented for 3 years.
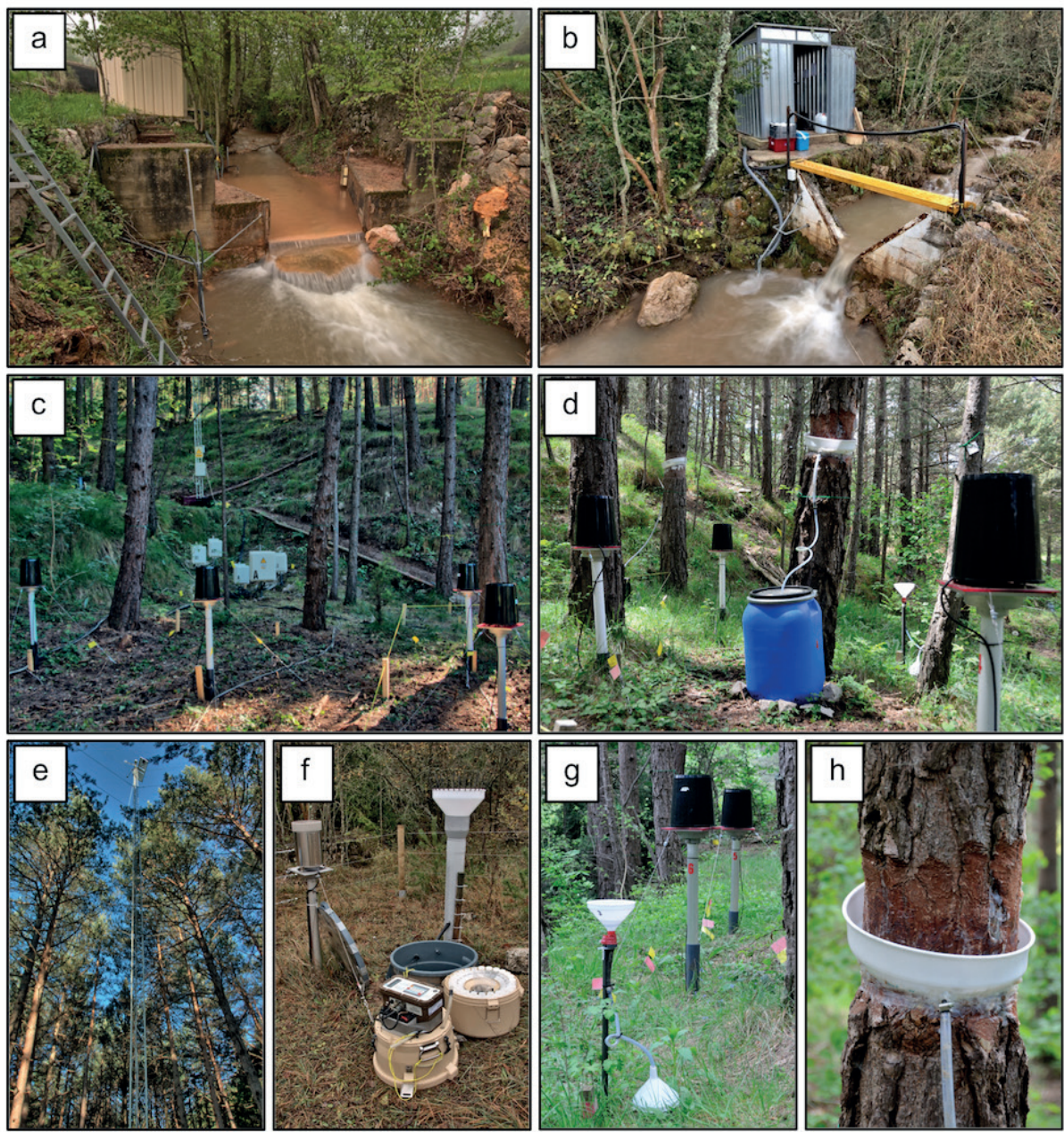

Figure 3. Gauging station of the Cal Rodó catchment $\left(4.17 \mathrm{~km}^{2}\right)(a)$ and of the Can Vila sub-catchment $\left(0.56 \mathrm{~km}^{2}\right)(b)$. Throughfall collectors, stemflow rings in the Cal Rotes plots (Scots Pine) $(c, d, g, h) .18$-meter meteorological tower in the Cal Rotes plot for measuring above-canopy conditions (e). Rainfall recorder and sequential rainfall sampler (5 mm rainfall increment $)(f)$. 


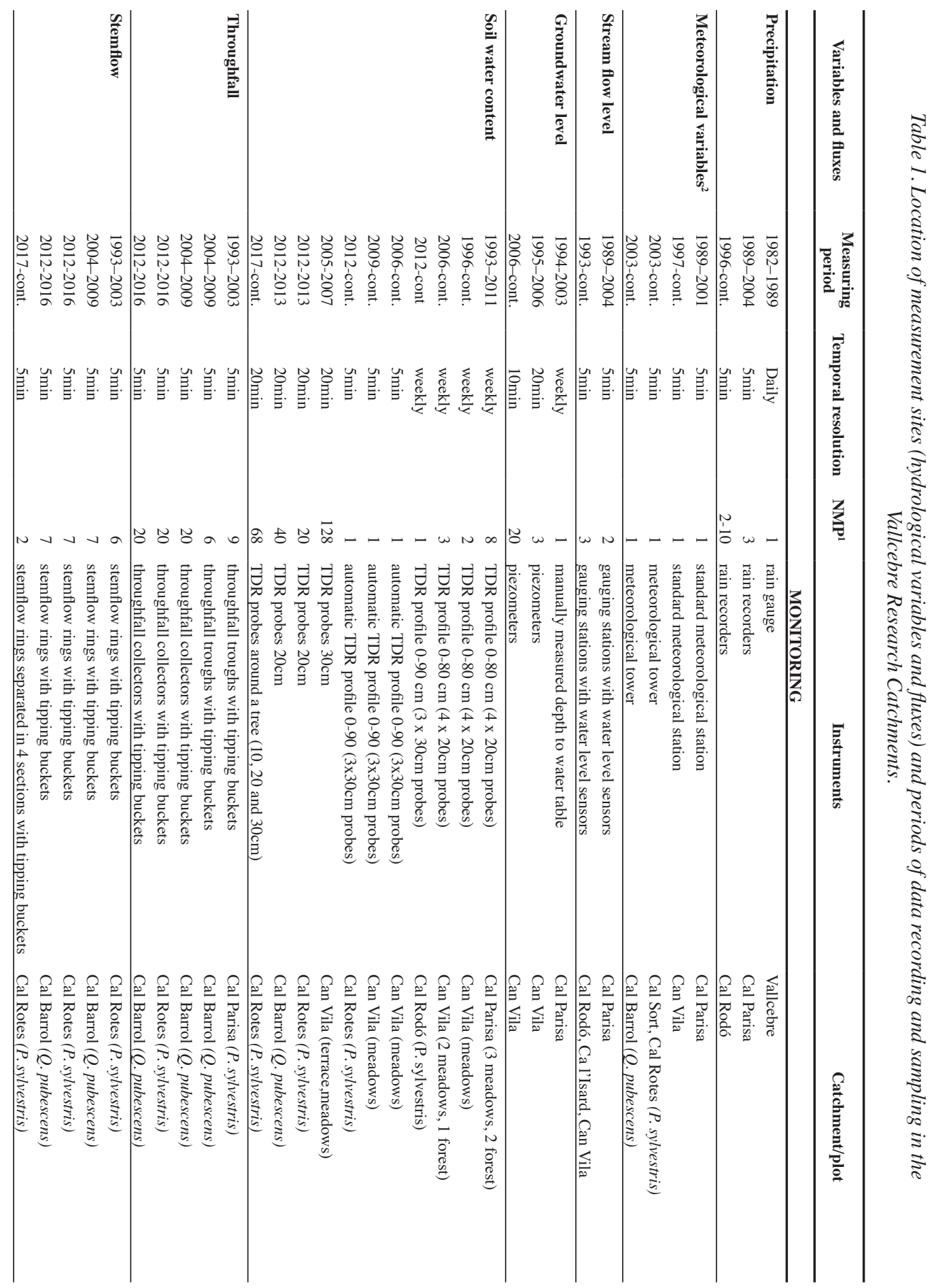




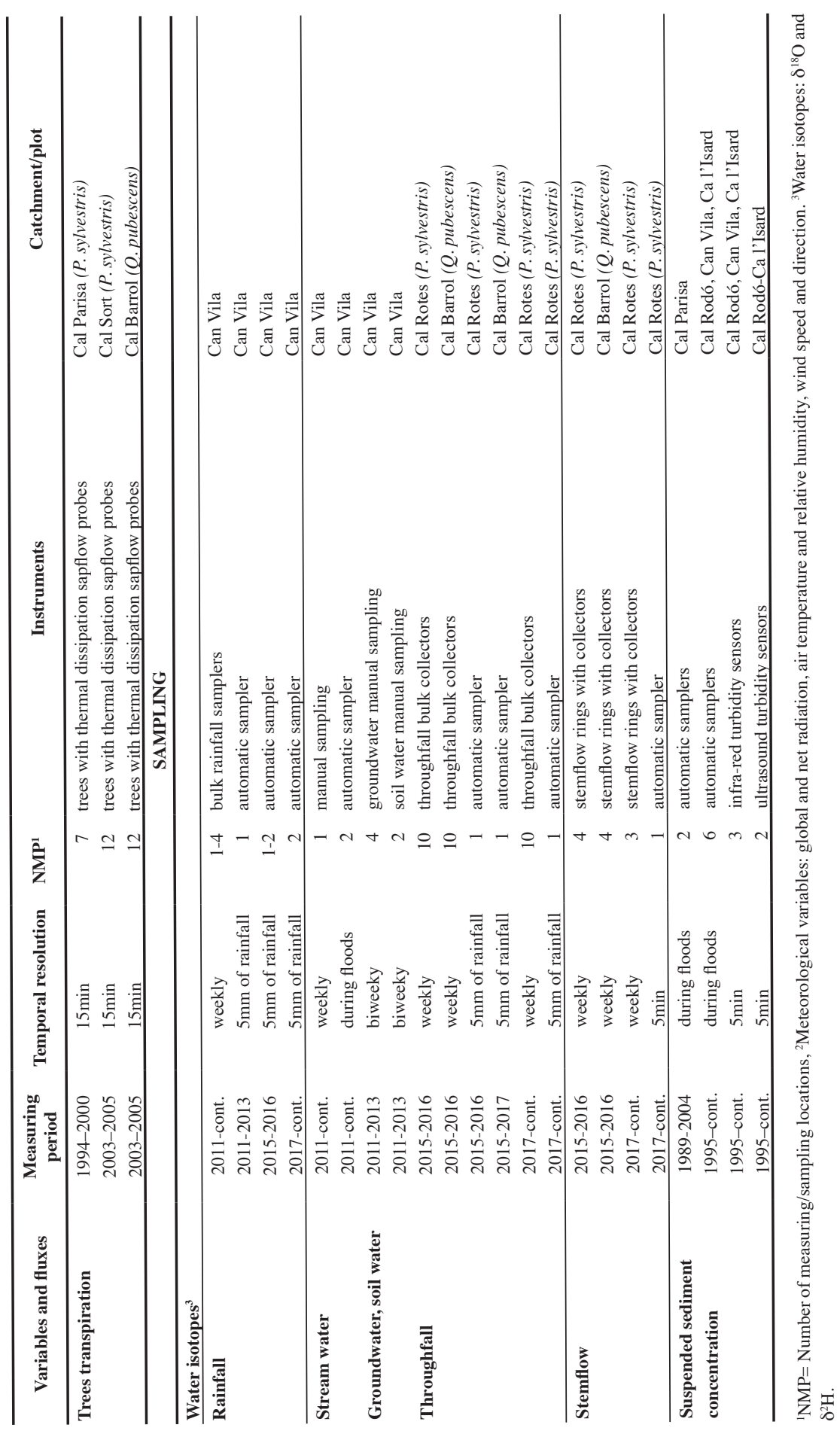




\section{What are we learning from the Vallcebre Research Catchments?}

The main results obtained since 1988 on rainfall and weather characteristics, ecohydrological processes as rainfall partitioning and forest transpiration, soil water content and piezometric level dynamics, hydrological response and runoff generation processes, as well as erosion and sediment transport, are summarized in the following sections.

\subsection{Rainfall, weather conditions and seasonality}

Climate can be defined as humid Mediterranean, characterized by a marked water deficit in summer. Long-term (1988-2013) mean annual precipitation was $880 \pm 200 \mathrm{~mm}$, with a mean 90 rainy days per year (Latron et al., 2009). Snowfall accounts for less than $5 \%$ volume over the period. The annual precipitation at Vallcebre is characterized by strong inter-annual variability, a range of variation of more than $700 \mathrm{~mm}$ between extreme values and a mean difference between consecutive years of more than $200 \mathrm{~mm}$.

The rainiest seasons are autumn and spring, with mean monthly rainfall amounts above $100 \mathrm{~mm}$ in October, November and May. Winter is the season with least precipitation. In summer, short convective storms may also provide significant precipitation input (Fig. 4 b). The spatial variability of rainfall within the catchment is limited, except during summer storms (Latron et al., 2009, 2010a).

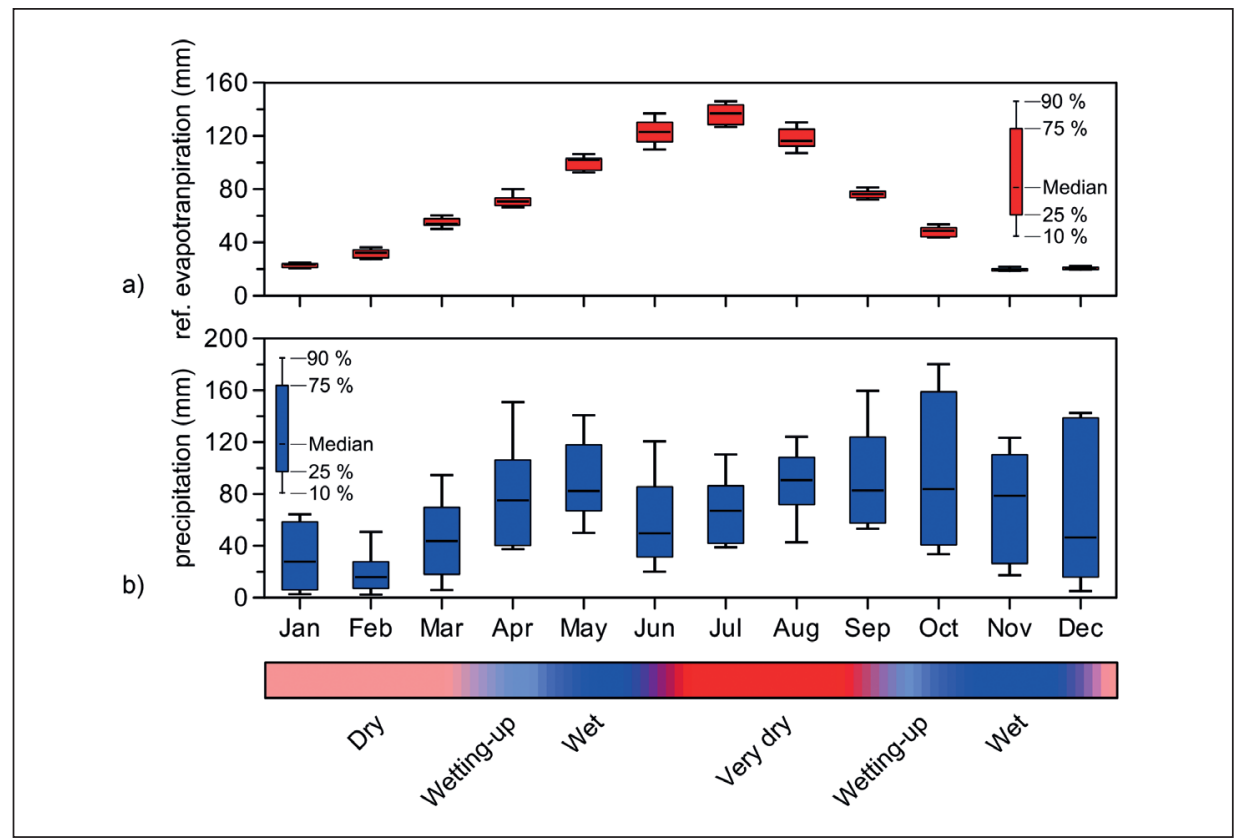

Figure 4. Annual distribution of monthly reference evapotranspiration (a) and precipitation (b) in the Vallcebre research catchments. The dynamics of rainfall and evaporative demand during the year cause the succession of dry and wet periods separated by wetting-up phases. 
In more than $60 \%$ of rainfall events, fewer than $6 \mathrm{~mm}$ fall; in $10 \%$, more than $25 \mathrm{~mm}$; and in only $3 \%$, more than $50 \mathrm{~mm}$. Nonetheless, on average, one or two rainfall events with over $100 \mathrm{~mm}$ are observed each year in the area. More than $80 \%$ of the rainfall events last fewer than 6 hours; summer is usually the season with shorter and more intense rainfall events. Mean rainfall intensities are generally lower than $6 \mathrm{~mm} \mathrm{~h}^{-1}$ except during the summer period. Maximum rainfall intensity in 20 minutes is less than $10 \mathrm{~mm}$ $\mathrm{h}^{-1}$ for $80 \%$ of the events. However, $7 \%$ of the rainfall events have a maximum rainfall intensity higher than $20 \mathrm{~mm} \mathrm{~h}^{-1}$. These events are most often summer storms with high intensities that may reach $80 \mathrm{~mm} \mathrm{~h}^{-1}$ in 20 minutes.

The isotopic signatures of meteoric waters in Vallcebre are influenced by the Western Mediterranean and Atlantic Ocean. The isotopic signature of rainfall in Vallcebre (20112016) was characterized by mean rainfall $\delta^{2} \mathrm{H}$ of $-44.14 \pm 25.67 \%$ o, $\delta^{18} \mathrm{O}$ of $-7.17 \pm$ $3.20 \%$ and deuterium excess of $13.19 \pm 5.79 \%$. The intra-annual pattern of rainfall $\delta^{18} \mathrm{O}$ followed the mean monthly air temperature, but no amount effect was observed (Casellas, 2017). At the event scale, most of the episodes selected had a V-shaped isotopic trend, followed by an L-shaped one. Very few episodes showed a constant trend.

Mean annual temperature at $1260 \mathrm{~m}$ a.s.1. is $9.1^{\circ} \mathrm{C}$ and long-term (1989-2006) mean annual reference evapotranspiration, calculated by the Hargreaves-Samani (1982) method, is $818 \pm 30 \mathrm{~mm}$. The reference evapotranspiration follows the characteristic yearly distribution (Fig. 4a), with low evaporative demand in winter, about $20 \mathrm{~mm}$ in December and January due to low temperatures, and high evaporative demand in summer, with a monthly maximum in July (up to $150 \mathrm{~mm}$ ). The combination of the seasonal rainfall distribution and the evaporative demand causes a succession of dry and wet periods during the year, separated by wetting-up phases (Fig. 4).

\subsection{Rainfall partitioning}

Rainfall partitioning for the two species studied, Scots pine and pubescent oak, indicates that throughfall is the dominant flux. Since mean throughfall and stemflow in Scots pine ran at $75 \%$ and less than $1.5 \%$, respectively, the interception rate was $24 \%$ of the incident precipitation. For oak, mean throughfall, including the periods with and without leaves, represented $83 \%$; and mean stemflow was slightly higher than $2 \%$. In this case the interception losses ran at about $15 \%$ of the incident precipitation (Fig. 5).

No seasonal control of rainfall interception was found for Scots pine (Gallart et al., 2002a). For this species, relative interception was similar throughout the year, due to the compensation between the characteristics of the events and the atmospheric conditions (Llorens et al., 1997). For oak the differences observed between the leafed and the leafless periods were less than expected. Thus, throughfall was about $3 \%$ lower and stemflow in the leafed period was reduced to half that in the leafless period. These differences resulted in a relative interception 5\% higher in the leafed period (Muzylo et al., 2012a). This small difference is due to a different combination of factors prevailing in each period. These factors are related to the differences in canopy storage capacity, rainfall intensity and wind speed during the two periods. In addition, the drying times 
of oak canopy are twice as long during the leaf period due to less ventilation inside the canopy (Llorens et al., 2014).

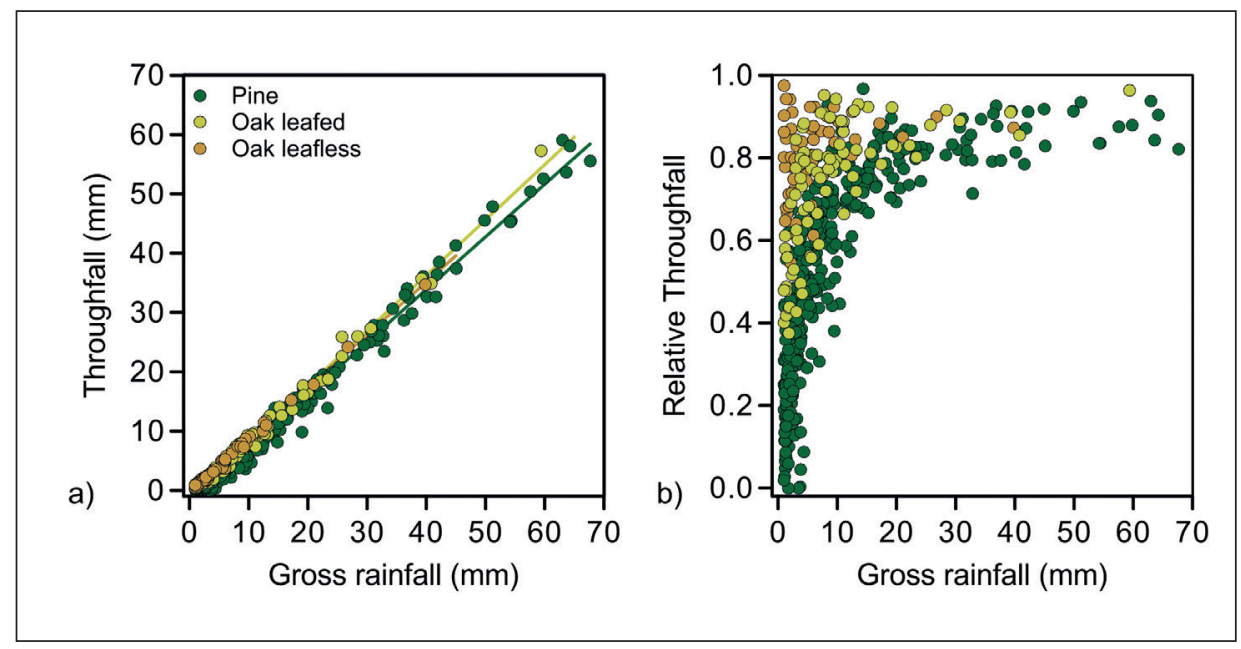

Figure 5. Throughfall as a function of incident precipitation for Scots pines and pubescent oaks leafed and leafless periods (a). Relative throughfall (throughfall divided by rainfall) as a function of incident precipitation for Scots pine and Downy oaks leafed and leafless periods (b).

At the inter-event scale short events with low rainfall intensities provide the highest interception rates, mainly due to their smaller rainfall volumes, whereas highintensity long events have the lowest interception rates (Llorens et al., 1997; Muzylo et al., 2012a). The high inter-event variability of interception losses in Mediterranean conditions, described by several authors (Llorens et al., 2011), can be attributed to the characteristics of the Mediterranean precipitation regime. Low-intensity events, which cause significant interception losses, are characteristic of frontal rains (e.g. Llorens et al., 1997; Limousin et al., 2008), while high-intensity events, which cause low interception rates, are promoted by convective storms (e.g. Llorens et al., 1997; David et al., 2005).

Results of rainfall partitioning modelling indicate that the original analytical Gash (1979) model, applied to the pine stand (Llorens, 1997), and the modified disperse Gash (Valente et al., 1997) and Rutter (Gash et al., 1995) models, applied to the oak stand (Muzylo et al., 2012b) are sufficiently robust to estimate interception losses in Mediterranean conditions. Likewise, the errors of the predictions are similar to those obtained in other climates or for other species (Muzylo et al., 2009). However, when model results were evaluated at the event scale, prediction errors were greater. The main reason is that, with the Gash model, a constant ratio between evaporation and rainfall rate does not allow correct simulation of the great variability of rainfall events observed in Mediterranean conditions (Limousin et al., 2008; Llorens, 1997). 
A detailed study of the stemflow dynamics of pine and oak (Cayuela et al., in review a) indicated that differences in this flux were controlled by rainfall amount and intensity. In addition, trees' biometric characteristics were the factors differentiating the response of each tree to the same rainfall event. In fact, this study emphasizes the need of combining both biotic and abiotic factors to understand stemflow dynamics. Moreover, despite the underestimation of stemflow in most hydrological studies because it represents only a small percentage of incident rainfall (Levia and Frost, 2003; Levia and Germer, 2015), stemflow intensities, much greater for some moments than the intensity of rainfall, highlight the paramount role of stemflow as a hotspot of infiltration and soil water content dynamics.

Recent work at the plots studied on the modification of the isotopic signature $\left(\delta^{18} \mathrm{O}\right.$ and $\left.\delta^{2} \mathrm{H}\right)$ of rainfall when passing through the canopies showed a shift in the isotopic composition of throughfall and stemflow with respect to open rainfall. In general, throughfall and stemflow tended to be more enriched in $\delta^{18} \mathrm{O}$ than open rainfall did, although some cases of depletion were found (Cayuela et al., in review b). The modification of rainfall isotopic signature by throughfall and stemflow is attributed to the interaction of three factors: evaporation, isotopic exchange between vapour and liquid and selective canopy storage (Allen et al., 2017). The analysis of these processes that take place in the canopy is of paramount importance when tracing the source and movement of water through forested or partially forested catchments (Klaus and McDonnell, 2013).

\subsection{Forest transpiration and ecohydrological processes}

Transpiration of the Scots pine was double that of the nearby pubescent oak (Poyatos et al., 2005), largely due to differences in the leaf area index between the stands. Maximum transpiration rates at optimal soil water content conditions were higher in the Scots pine stand than in the pubescent oak stand. However, when soil water content became a limiting factor, transpiration in the Scots pines dropped considerably, whereas the pubescent oaks were less affected by soil water-content deficits. The physiological responses to water deficits of both species indicated that Scots pine was more vulnerable to xylem embolism, whereas pubescent oak was more resistant to extreme drought events (Poyatos et al., 2008). There was a $40 \%$ greater reduction of Scots pine total summer transpiration during dry summers than in a summer with average rainfall. Moreover, full transpiration recovery after significant rainfall events was not observed during dry summers, which could indicate some lasting drought effects, like the embolism mentioned above (Llorens et al., 2010). Likewise, the relationship found between climate characteristics and growth indicates a strong effect of past growth trends and current water use strategies on tree resilience to increased aridity, which is more evident in Scots pine (Morán-López et al., 2014). The large proportion of rainfall used for Scots pine transpiration during dry summers results in a strong reduction of runoff and deep water stores at the catchment scale, suggesting that the predicted increase in the frequency of severe summer droughts may threaten the current role of Mediterranean mountain catchments as suppliers of water resources for lowland areas (Llorens et al., 2010). 
Sapflow data measured at the pine plot have been included in several metaanalyses of Pinus sylvestris' physiological adjustment to climatic conditions, growth and resistance to drought (Poyatos et al., 2007; Martinez-Vilalta et al., 2009; Sterck et al., 2012). Likewise, sapflow data, combined with rainfall, meteorological and soil water content data, have been used to validate remote sensing (Cristobal et al., 2011) and modelling approaches (De Cáceres et al., 2015; Sus et al., 2014).

Recently, a dual isotope-based approach $\left(\delta^{18} \mathrm{O}\right.$ and $\left.\delta^{2} \mathrm{H}\right)$ has been used to examine the mixing of water in the soil and the linkages between tree water fluxes and soil water pools. Preliminary results indicate that stable isotope ratios of bound soil water fell below the local meteoric water line (LMWL), with more evaporative enrichment in the shallow horizons. On the contrary, mobile soil water (low suction cup lysimeters) and groundwater fell along the LMWL, well mixed with stream water.

\subsection{Soil water content and piezometric level dynamics}

At the catchment scale, soil water content shows a seasonal pattern characterized by the occurrence of periods of marked deficit in summer and, though less pronounced, in winter (Fig. 6a). The spatial variability of soil water content $(0-80 \mathrm{~cm}$ depth profiles) was not consistent throughout the year. Differences were minimal during the driest and wettest conditions, whereas the greatest differences between locations were observed under intermediate moisture conditions (Fig. 6b), during the drying and wetting-up periods (García-Estringana et al., 2013). Soil water content during wetting-up and drying-down periods probably depended mainly on local controls (Grayson et al., 1997), such as vegetation and soil properties. In fact, results indicated (Fig. 6c) that soil water content on hillslopes under forest cover was lower than in downslope areas covered by grasses (Gallart et al., 1997, 2002a). However, during wet conditions, soil water content patterns were controlled by non-local factors. Under these conditions, the general topographic features of the catchment, favouring water redistribution, limited the effect of the vegetation on soil water content spatial patterns (Garcia-Estringana et al., 2013).

Results of soil water content spatial variability monitored on one abandoned agricultural terrace showed that, at the daily scale, variability increased with soil water content. Moreover, as observed at the catchment scale, a low effect of local controls under dry conditions and a higher effect of non-local controls under wetter conditions were observed. At this spatial scale the main non-local control observed on soil water content was the distance of each location from the inner part of the terrace, because the inner parts of the terraces are areas prone to saturation due mainly to shallow soil depth (Molina et al., 2014). With this information the representativeness of different spatial and temporal designs were tested. Results indicated that $10 \mathrm{x} 10 \mathrm{~m}$ grids were a robust design for obtaining a good estimation of mean soil water content dynamics. During wetting-up periods the longest time-step that could detect rapid changes in soil water content was $8 \mathrm{~h}$, whereas during drying-down periods soil water content monitoring frequency of $24 \mathrm{~h}$ was enough to catch changes in water balance (Molina et al., 2014). 
a)

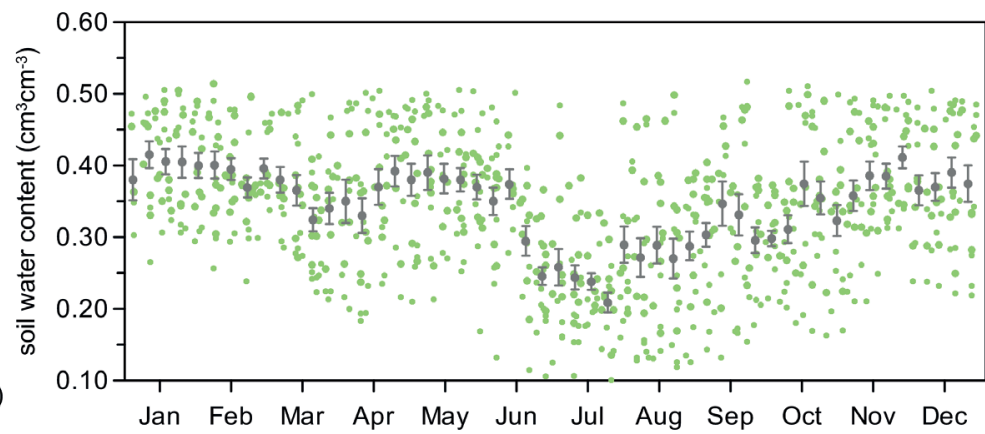

b)
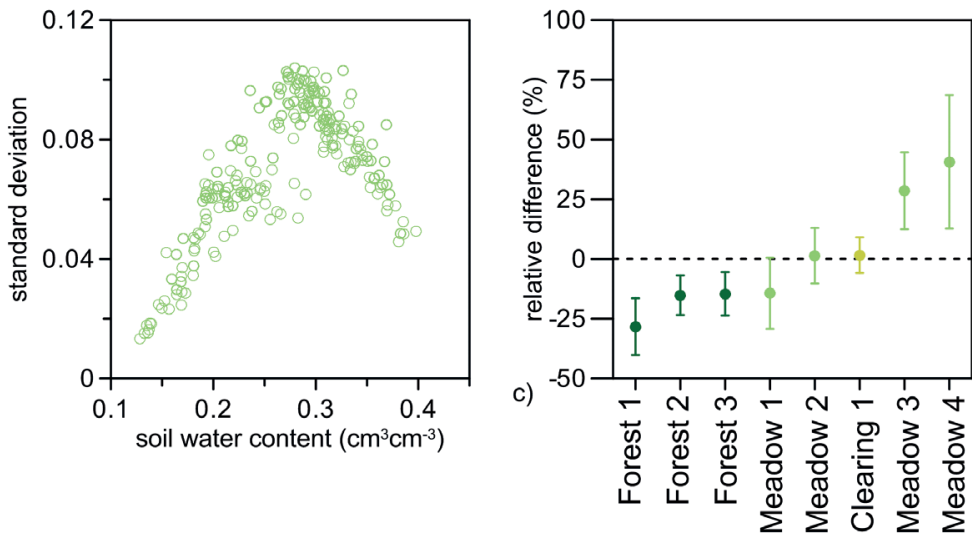

Figure 6. Intra-annual evolution (weekly measurements from 1994 to 2003) of mean soil water content at a mid-slope location, in the Cal Parisa catchment (a). Grey dots correspond to mean values and standard errors obtained from all available measurements for a given week. Relationship between mean soil water content (averaged from different locations in the Cal Parisa catchment) and its standard deviation as an indicator of soil water content spatial variability $(b)$. Ranked values (from dry to wet) of the relative difference between the mean soil water content value of each location and mean value of all the locations in the Cal Parisa catchment (c).

Error bars $= \pm 1$ standard deviation. DOY: Day Of the Year.

Shallow groundwater dynamics also show a seasonal pattern at the catchment scale. During the summer period, the water table drops markedly every year in response to increasing evapotranspiration (Fig 7a). As for soil water content, the water table rises steadily during the wetting-up period in response to autumn rainfall events and often remains in the first $50 \mathrm{~cm}$ below the surface during winter and spring.

The analysis of shallow groundwater dynamics during rainfall-runoff events indicated marked spatial variability, controlled mainly by the distance of the measuring location (piezometer) from the stream (Fig. 7b). The analysis of the effect 
of antecedent wetness conditions on runoff generation distinguished three processes. In dry conditions, with a marked spatial variability of piezometric levels, shallow groundwater located near the stream channel was the main contributor to stormflow. In intermediate conditions, there was a more generalized response of shallow groundwater to rainfall, though the timing between different locations was variable. Finally, in wet conditions a pre-event water table close to the soil surface gave more homogeneous responses (Latron and Gallart, 2008; Latron et al., 2010; RoigPlanasdemunt et al., submitted).

a)

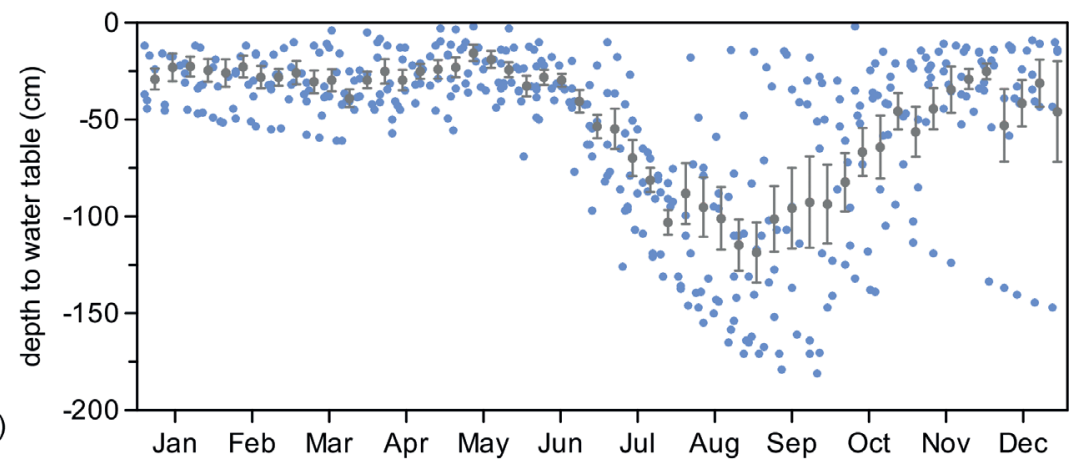

b)
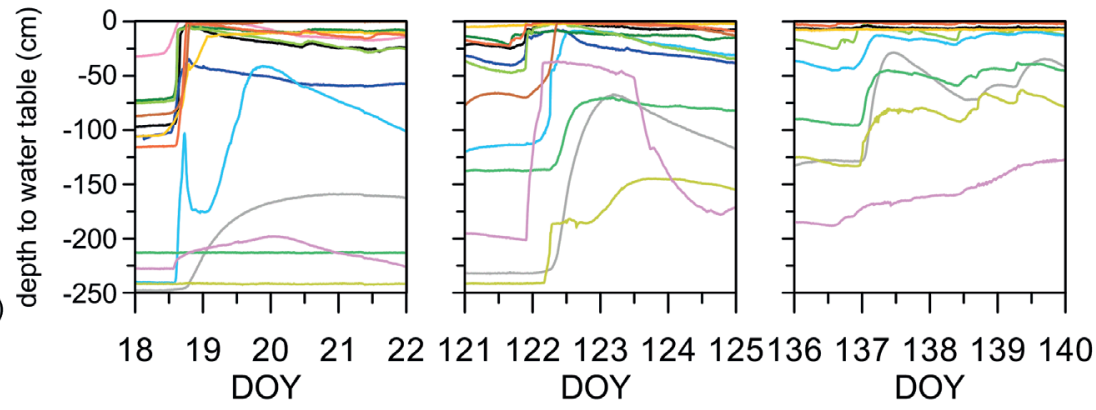

Figure 7. Intra-annual evolution (weekly measurements from 1994 to 2003) of water table depth, in the Cal Parisa catchment. Grey dots correspond to mean values and standard errors obtained from all available measurements for a given week (a). Depth to water table dynamics observed at 13 piezometer locations in the Can Vila catchment, during floods occurring in dry (left), wettingup (middle) and wet (right) conditions (b). DOY: Day Of the Year.

\subsection{Hydrological response and runoff generation processes}

During the water years 1995-2012, mean annual runoff in the Cal Rodó catchment was $210 \pm 121 \mathrm{~mm}$ (equivalent to $25 \%$ of rainfall) and in Can Vila it was $305 \pm 196 \mathrm{~mm}(36 \%$ of rainfall). In spite of this difference in annual runoff, related to the deep percolation in 
the limestone area of the Cal Rodó catchment, the relationship between annual runoff in both catchments was broadly linear. Mean daily discharge over the period was 6.7 $1 \mathrm{~s}^{-1} \mathrm{~km}^{-2}\left(\min =0 ; \max =1093 \mathrm{ls}^{-1} \mathrm{~km}^{-2}\right)$ in Cal Rodó and $9.7 \mathrm{ls}^{-1} \mathrm{~km}^{-2}$ in Can Vila (min=0; $\max =1024 \mathrm{ls}^{-1} \mathrm{~km}^{-2}$ ). However, stream-flow was highly seasonal, and the streams dried out in summer every 2 years on average, for a period ranging from 15 to 40 days. Streamflow is rather flashy in the Cal Rodó and Can Vila catchments, with response time of around one hour. Recessions are quite steep in the Cal Rodó catchment, but gentler in Can Vila.

There was no simple rainfall-runoff relationship on either seasonal or monthly scales. Monthly analysis revealed the existence of a threshold in the rainfall-runoff relationship, mainly due to the non-linearity observed between groundwater table and runoff, as indicated above (Latron et al., 2008). At the event scale, the storm-flow coefficient showed a clear seasonal pattern. During wet periods, at the end of autumn or beginning of winter, the highest storm-flow values were observed. In these conditions the catchment is hydrologically active and shows a significant response to precipitation. On the contrary, the lowest storm-flow values were observed during summer. Moreover, in dry conditions storm-flow coefficient variability was frequently two orders of magnitude larger than during wet conditions (Gallart et al., 1997; Latron et al., 1997, 2010). The relationships between the storm-flow coefficient and rainfall depth, rainfall maximum intensity and baseflow showed that the correlations found were the same as those observed for wet climates, even if correlation coefficients were notably lower (Latron et al., 2008).

The combined analysis of soil water tension, groundwater table dynamics and runoff contributing areas during floods identified three types of hydrological behaviour (Latron and Gallart, 2007, 2008) (Fig. 8). In dry conditions, only limited storm-flow response was observed at the catchment outlet due to, as indicated above, low groundwater tables and dry soils. Under these conditions, catchment response was fast and short: neither topsoil saturation nor water table rise were detected and thus no saturated area was observed (Latron and Gallart, 2007). For these events the only possible runoff-contributing areas were local, low-permeable areas (bedrock outcrops or badlands) close to the stream, with infiltration excess runoff probably the dominant runoff process. During transitions from dry to wet conditions, as a response to more frequent and/or greater rainfalls, larger runoff events with moderate storm-flow coefficients were observed. These events were characterised by a long response time and a relatively gentle recession. A scattered saturation pattern, due to a perched saturation layer reaching the surface at some places favoured by the terraced topography and soil characteristics, was observed during these conditions (Latron and Gallart, 2007). Saturation excess overland flow on perched saturated layers was probably the dominant runoff generation process during the wetting-up periods. In wet conditions, when the catchment was saturated or close to saturation, large and lasting runoff response was observed. In these conditions, the shallow groundwater table rose quickly, causing saturated areas to expand rapidly. Excess overland flow on saturated areas was most probably the main runoff generation process in these conditions. 

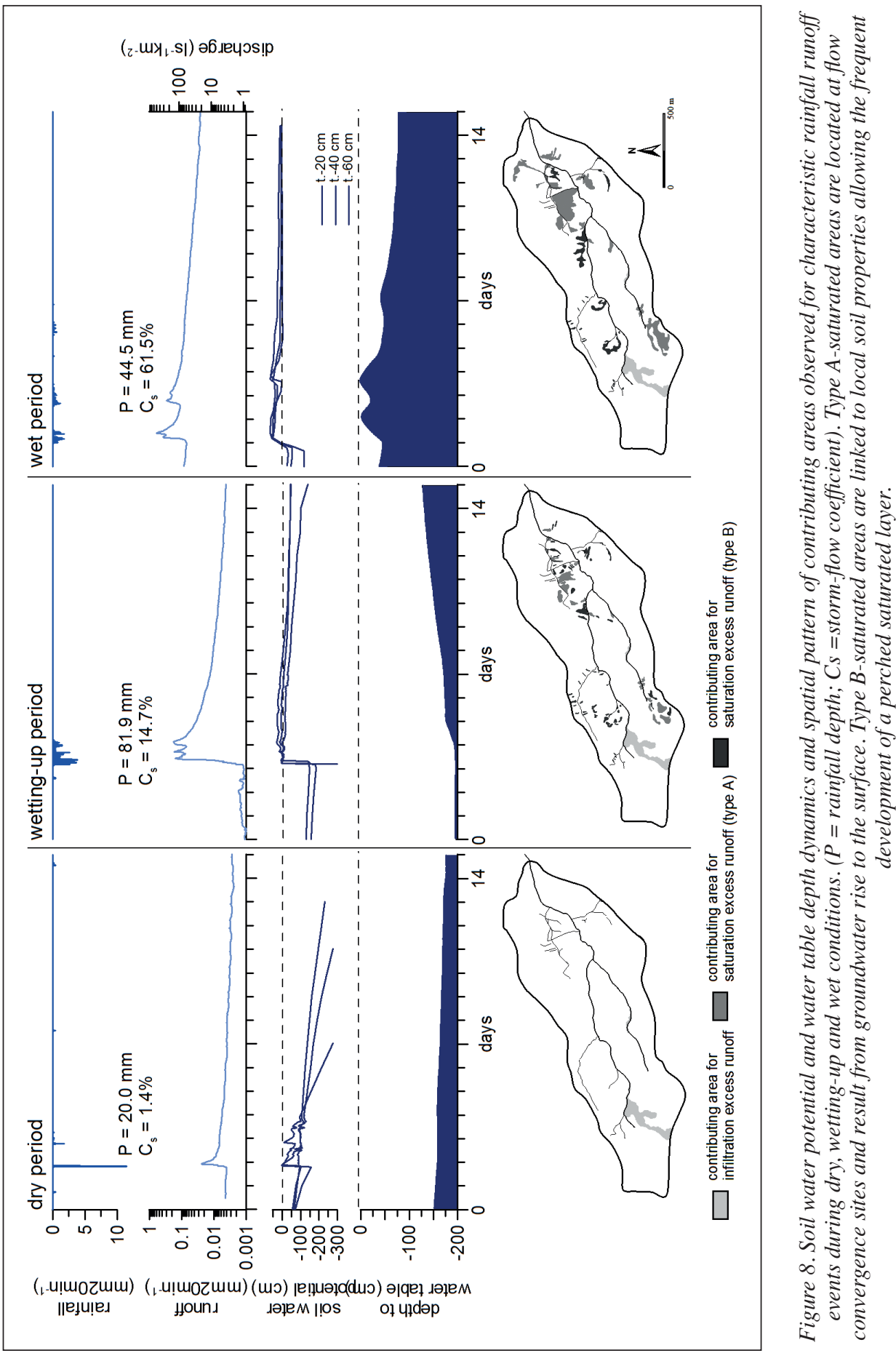


\subsection{Environmental tracers and transit time}

The study of dissolved organic carbon (DOC) dynamics in the Can Vila catchment showed some seasonality in precipitation and soil water, both related to biological activity (Roig-Planasdemunt et al., 2017). However, no clear seasonality was observed in groundwater, where DOC and water table dynamics were closely related. On the other hand, DOC in stream water was clearly dependent on discharge, but there was discontinuity, which depended on the magnitude of the discharge. Low and constant DOC concentrations were observed for low flow conditions $\left(<20 \mathrm{l} \mathrm{s}^{-1} \mathrm{~km}^{-2}\right)$, whereas DOC concentration increased as discharge increased during flood conditions. The increase in stream water DOC concentration during floods suggests a relevant contribution of soil water. Moreover, a DOC flushing effect observed at the first discharge peak, in events with several peaks, suggests the presence of DOC sources in the streambed. However, similar stream water DOC dynamics were observed during storm events with diverse antecedent conditions and event characteristics, raising the question of the origin of rapid DOC increase during floods.

Two-component hydrograph separation results, using stable isotopes in the Can Vila catchment, indicate that pre-existing water contributed between $30 \%$ and almost $100 \%$ to total runoff (Fig. 9), depending on antecedent moisture conditions, the extent of saturated areas within the catchment and precipitation characteristics (Latron et al., 2015). During low to moderate intensity rainfall events (winter, spring, autumn), old water contribution was dominant along the hydrographs; new water contribution was always less than $10 \%$. Conversely, during high-intensity summer storms, old water contribution in the hydrograph was lower (30\% to $50 \%)$ and the response corresponded mostly to new water. A negative correlation was found between maximum rainfall intensity and old water contribution at the event scale. In addition, the lower the old water contribution in the hydrograph, the higher the maximum suspended sediment concentration observed at the outlet, which suggests that summer floods were mainly caused by infiltration excess runoff generated on badlands and degraded areas of the catchment (Latron et al., 2015). 


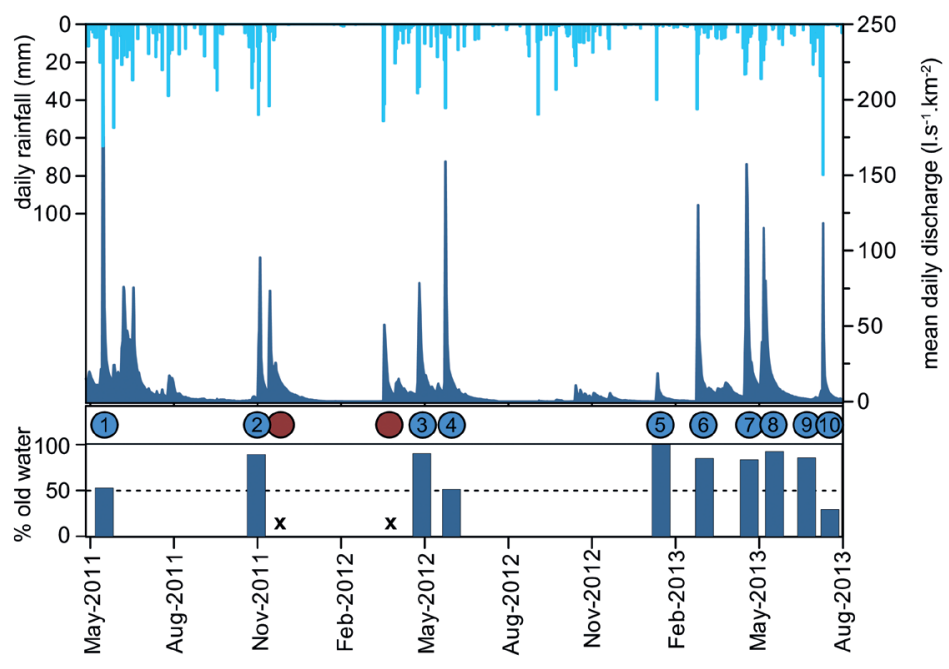

Figure 9. Time series of daily rainfall and mean daily discharge measured in the Can Vila catchment (May 2011-July 2013). Numbers from 1 to 10 refer to floods sampled for stable isotopes. Old water contribution derived from two-component hydrograph separation (180) is shown for each flood. Red circles correspond to two floods for which hydrograph separation was not possible because of similar isotopic signals in rainfall and in the stream before the flood.

A new methodology to assess the mean transit time (MTT) and its uncertainty was recently developed and applied to the Vallcebre research catchments (Gallart et al., 2016). This methodology, using a general likelihood uncertainty assessment (GLUE), takes into account both the analytical and model parameter errors. Using a resampling procedure, it determines the statistical significance of the MTT differences found between pairs of sampled sites. This methodology was applied to Tritium samples taken during steadystate baseflow periods in diverse streams, wells and springs in the Vallcebre research catchments in the late nineties (1996-1998) by Hermann et al. (1999) and in 2013. Results indicate that water samples can be classified in three main groups, consistent with the geological setting of the catchment: shallow open aquifers with MTT of nearly $5 \mathrm{yrs}$; spring and stream waters from one subcatchment with MTT of nearly $7.5 \mathrm{yrs}$; and from another subcatchment, with MTT of nearly $12 \mathrm{yrs}$. These results support the use of tritium in MTT studies to gain information about old waters not identifiable by stable isotopes (Gallart et al., 2016).

\subsection{Erosion and sediment transport processes}

Badlands are the main sediment sources in the Vallcebre research catchments. To understand the erosion and sediment dynamics of these areas, two main approaches have been used (see Gallart et al., 2013 for a review). On the one hand, short-term studies calculated denudation rates and sediment production at the plot 
scale, to analyse weathering seasonal dynamics and to study the relationships between geomorphic activity and herbaceous plant colonisation. On the other hand, long-term studies (1990 till now) studied suspended sediment dynamics at the catchment scale. Results indicate that ground freezing in winter is the main weathering mechanism, whereas erosion is especially active in summer due to both the availability of erodible material and the occurrence of intense rain events. However, the eroded sediments may remain deposited in the streams from months to years (Gallart et al., 2013).

Results on denudation rates and sediment production at the plot scale gave rates between 11,000 and $23,000 \mathrm{Mg} \mathrm{km}^{-2} \mathrm{yr}^{-1}$, depending on the method used. The uncertainty of these estimates was analysed by applying the KINEROS2 model to a set of badland areas for a period of 15 years, giving a long-term sediment production of about $9000 \mathrm{Mg} \mathrm{km}^{-2} \mathrm{yr}^{-1}$. This also allowed a detailed analysis of the temporal patterns of the erosive events (Martínez-Carreras et al., 2007). Results at the catchment scale, recorded for 18 years at the Ca l'Isard subbasin (with $4.5 \%$ of the surface covered by badlands), showed a sediment yield of $534 \mathrm{Mg} \mathrm{km}^{-2} \mathrm{yr}^{-1}$. In addition, this long-term record allowed us to analyse the uncertainty of the measurements associated with the length of the recording period. The combination of the three approaches, plot and catchment scales and modelling, demonstrated that records longer than 5 years are needed to assess the order of magnitude of the erosion or transport rates (Gallart et al., 2013).

Recently, the assessment of sediment connectivity was analysed by use of lead-210 $\left({ }^{210} \mathrm{~Pb}\right.$ ex $)$ fallout in the Cal Rodó catchment. Results indicated low sediment ${ }^{210} \mathrm{~Pb}_{\mathrm{ex}}$ concentrations in both the sediments deposited in the streambed and the suspended sediments. These low concentrations are the result of the fresh-rock origin of sediments eroded in badland areas. Results indicated that fine suspended sediment ${ }^{210} \mathrm{~Pb}_{\text {ex }}$ activity follows the seasonal pattern of fallout accumulation during most of the year and erosion by summer storms, and that ${ }^{210} \mathrm{~Pb}_{\mathrm{ex}}$ activity in fine suspended sediments decreased towards the catchment outlet. These results suggest high connectivity between the badlands, streams and catchment outlet for fine sediments, but much lower connectivity of sandy or coarser sediments eroded from badland surfaces and untagged by the fallout, as they mainly remain in the stream bed (Moreno de las Heras et al., 2017).

Badlands at Vallcebre, and more generally in the high Llobregat catchment, are examples of humid badlands (Gallart et al., 2002b, 2013). In these intensely eroded areas, vegetation is not limited by dryness (as in arid or semi-arid badlands), but by the severe weathering and erosion processes driven by freezing-thawing processes and summer convective storms, respectively (Regüés et al., 2000). Vegetation is more abundant and diverse on sunny (south-facing) aspects than on shady ones because low winter temperature is a more limiting factor than summer drought for Mediterranean species (Guàrdia et al., 2000). Badland surfaces develop on north-facing aspects or those with no clear orientation, depending on the higher or lower strength of bedrock (Morenode las Heras and Gallart, 2016). 


\section{Conclusions}

Thirty years of research in the Vallcebre Research Catchments have increased understanding not only of their hydrological response, but also of the main hydrological and erosion processes characteristic of Mediterranean mountain catchments.

The main findings from this research are the following:

- The marked temporal variability in precipitation, both intra-annual and seasonal, clearly determines the hydrological processes.

- The high inter-event variability of interception losses can be attributed to the characteristics of the Mediterranean precipitation regime, which includes frontal rains and convective storms, producing high and low interception losses, respectively.

- There is a general tendency for throughfall and stemflow to be more $\delta^{18} \mathrm{O}$ enriched than bulk rainfall.

- Scots Pine is more vulnerable to drought than pubescent oak. Moreover, the large proportion of rainfall used for Scots pine transpiration during dry summers results in a strong reduction of runoff and water stores.

- Forest cover, as against meadows, plays a paramount role in reducing soil water content during intermediate moisture conditions.

- There is a low effect of local controls on soil water content under dry conditions and a higher effect of non-local control under wetter conditions, at catchment and plot scales.

- There is a marked influence on runoff generation of antecedent wetness conditions, soil water content and shallow groundwater.

- Complex rainfall-runoff relationships at seasonal and monthly scales were observed, determined by the non-linearity between groundwater and runoff responses.

- There were three types of hydrological behaviour: areas contributing partially during dry periods, a wetting-up transition period characteristic of Mediterranean catchments and behaviour similar to those reported for humid climates in wet conditions.

- During floods, the contribution of pre-existing water is often dominant.

- There is no clear indication of DOC origin during the different type of floods.

- Mean transit time determination supports the use of tritium to identify old waters, not identifiable by stable isotopes.

- Records longer than 5 years are needed to assess the magnitude of erosion or transport rates.

- Badlands at Vallcebre provide examples of humid badlands, where vegetation is controlled by severe weathering, and erosion driven by freezing-thawing processes and summer convective storms. 


\section{Acknowledgements}

The 30 years of research in the Vallcebre catchments have been carried out with the support of various research projects funded by the Spanish government and the European Community. Among these are the two current projects: TransHyMed (CGL2016-75957-R AEI/FEDER, UE) and MASCC-DYNAMITE (PCIN-2017061/AEI). Research into the Vallcebre catchments also received funding from the convention between the CSIC and the MAPAMA (RESEL). C. Cayuela is beneficiary of a pre-doctoral FPI grant (BES-2014-070609), A. Molina and M. Moreno de las Heras are beneficiaries of contracts within the "Juan de la Cierva" program (FJCI2015-24597 and IJCL-2015-26463, respectively), funded by the Spanish Ministry of Economy, Industry and Competitiveness, and G. Bertran is beneficiary of a contract within the program "Sistema Nacional de Garantía Juvenil" (CS2_CAT_ IDAEA_049). The authors are very grateful to all those who have collaborated in the research carried out during these 30 years, and especially to: O. Ávila, X. Huguet, P. García-Estringana, R. Poyatos, D. Regüés, C. Rubio and M. Soler.

\section{References}

Aepler, R. 1968. Das Garumnium der Mulde von Vallcebre und ihre Tektonik (Spanien, Provinz Barcelona). Freie Universität Berlin, Berlin, $101 \mathrm{pp}$.

Allen, S.T., Keim, R.F., Barnard, H.R., McDonnell, J.J., Renée Brooks, J. 2017. The role of stable isotopes in understanding rainfall interception processes: a review. WIREs Water 2017, 4, null. http://doi.org /10.1002/wat2.1187.

Beven, K. 2016. Advice to a young hydrologist. Hydrological Processes 30 (20), 3578-3582. http://doi.org /10.1002/hyp.10879.

Burt, T., McDonnell, J. 2015. Whither field hydrology? The need for discovery science and outrageous hydrological hypotheses. Water Resources Research 51 (8), 5919-5928. http:// doi.org /10.1002/2014WR016839.

Casellas, E. 2017. Characteristics and intra-event scale variability of rainfall isotopic signature in a Mediterranean mountain catchment (Vallcebre, eastern Pyrenees), Universitat de Barcelona, Unpublished Master Thesis, Barcelona, 14 pp.

Castelltort, X. 1995. Erosió, transport i sedimentació fluvial com a integració dels processos geomorfològics d'una conca (Conca de Cal Rodó, Alt Llobregat), Universitat de Barcelona Unpublished PhD Thesis, Barcelona, 234 pp.

Cayuela, C., Llorens, P., Sánchez-Costa, E., Levia, D., Latron, J. In review a. Respective importance of biotic and abiotic factors on stemflow production from oak and pine stands at inter- and intrastorm scales in a Mediterranean mountain. Journal of Hydrology.

Cayuela, C., Llorens, P., Sánchez-Costa, E., Latron, J. In review b. Intra-event dynamics of stable isotopes in throughfall under Scots pine and Downy oak forest. Hydrological Processes.

Cristóbal, J., Poyatos, R., Ninyerola, M., Llorens, P., Pons, X. 2011. Combining remote sensing and GIS climate modelling to estimate daily forest evapotranspiration in a Mediterranean mountain area. Hydrology and Earth System Sciences 15 (5), 1563-1575. http://doi.org /10.5194/hess-15-1563-2011.

David, J.S., Valente, F., Gash, J.H. 2005. Evaporation of intercepted rainfall. In: M. Anderson, Encyclopedia of Hydrological Sciences. John Willey, Chichester, pp. 2713-2726.

De Cáceres, M., Martínez-Vilalta, J., Coll, L., Llorens, P., Casals, P., Poyatos, R., Pausas, J., Brotons, L. 2015. Coupling a water balance model with forest inventory data to predict 
drought stress: the role of forest structural changes vs. climate changes. Agricultural and Forest Meteorology 213, 77-90. http://doi.org/10.1016/j.agrformet.2015.06.012.

Gallart, F., Llorens, P., Latron, J. 1994. Studying the role of old agricultural terraces on runoff generation in a small Mediterranean mountainous basin. Journal of Hydrology 159(1-4), 291-303. https://doi.org/10.1016/0022-1694(94)90262-3.

Gallart, F., Latron, J., Llorens, P., Rabada, D. 1997. Hydrological functioning of Mediterranean mountain basins in Vallcebre, Catalonia: Some challenges for hydrological modelling. Hydrological Processes 11 (9), 1263-1272. http://doi.org /10.1002/(SICI)10991085(199707)11:9<1263::AID-HYP556>3.0.CO;2-W.

Gallart, F., Llorens, P., Latron, J., Regüés, D. 2002a. Hydrological processes and their seasonal controls in a small Mediterranean mountain catchment in the Pyrenees. Hydrology and Earth System Sciences 6 (3), 527-537. https://doi.org/10.5194/hess-6-527-2002.

Gallart, F., Solé, A., Puigdefábregas, J., Lázaro, R. 2002b. Badland systems in the Mediterranean. In: L.J. Bull, M.J. Kirkby, (Eds.), Dryland rivers: hydrology and geomorphology of semiarid channels. John Wiley and Sons Ltd., Chichester, UK, pp. 299-326.

Gallart, F., Latron, J., Llorens, P. 2005. Catchment dynamics in a Mediterranean mountain environment. The Vallcebre research basins (southeastern Pyrenees). I. Hydrology. In: C. García, R.J. Batalla (Eds.) Catchment dynamics and river processes in Mediterranean and other climate regions. Developments in Earth Surface Processes, vol. 7, pp. 1-16.

Gallart, F., Prat, N., García-Roger, E. M., Latron, J., Rieradevall, M., Llorens, P., Barberá, G.G., Brito, D., De Girolamo, A.M., Lo Porto, A., Buffagni, A., Erba, S., Neves, R., Nikolaidis, N.P., Perrin, J.L., Querner, E.P., Quiñonero, J.M., Tournoud, M.G., Tzoraki, O., Skoulikidis, N., Gómez, R., Sánchez-Montoya, M.M., Froebrich, J. 2012. A novel approach to analysing the regimes of temporary streams in relation to their controls on the composition and structure of aquatic biota. Hydrology and Earth System Sciences 16, 3165-3182. https://doi. org/10.5194/hess-16-3165-2012.

Gallart, F., Marignani, M., Pérez-Gallego, N., Santi, E., Maccherini, S. 2013. Thirty years of studies on badlands, from physical to vegetational approaches. A succinct review. Catena 106, 4-11. https://doi.org/10.1016/j.catena.2012.02.008.

Gallart, F., Roig-Planasdemunt, M., Stewart, M.K., Llorens, P., Morgenstern, U., Stichler, W., Pfiter, L., Latron, J. 2016. A GLUE based uncertainty assessment framework for tritiuminferred transit time estimations under baseflow conditions. Hydrological Processes 30 (25), 4741-4760. https://doi.org/10.1002/hyp.10991.

García-Estringana, P., Latron, J., Llorens, P., Gallart, F. 2013. Spatial and temporal dynamics of soil moisture in a Mediterranean mountain area (Vallcebre, NE Spain). Ecohydrology 6 (5), 741-753. https://doi.org/10.1002/eco.1295.

Gash, J.H.C. 1979. An analytical model of rainfall interception by forests. Quarterly Journal of the Royal Meteorological Society 105(443), 43-55. https://doi.org/10.1002/qj.49710544304.

Gash, J.H.C., Lloyd, C.R., Lachaud, G. 1995. Estimating Sparse Forest Rainfall Interception with an Analytical Model. Journal of Hydrology 170(1-4), 79-86. https://doi.org/10.1016/00221694(95)02697-N.

Grayson, R.B., Western, A.W., Chiew, F.H.S., Blöschl, G. 1997. Preferred states in spatial soil moisture patterns: Local and nonlocal controls. Water Resources Research 33 (12), 2897 2908. https://doi.org/10.1029/97WR02174.

Guàrdia, R., Gallart, F., Ninot, J.M. 2000. Soil seed bank and seedling dynamics in badlands of the Upper Llobregat basin (Pyrenees). Catena 40 (2), 189-202. https://doi.org/10.1016/S03418162(99)00054-5.

Hargreaves, G.H., Samani, Z.A. 1982. Estimating potential evapotranspiration. Journal of the Irrigation and Drainage Division 108 (3), 225-230. 
Haro, S., Fernández, J.F., Josa, R., Gallart, F. 1992. Papel hidroloógico y geomorfoloógico de las propiedades del suelo en una zona pirenaica de campos abandonados (Cal Parisa, Vallcebre). In: F. López-Bermúdez, C. Conesa, C., M.A. Romero, (Ed.), Estudios de Geomorfología en España. S.E.G., Murcia, pp. 243-250.

Herrmann, A., Bahls, S., Stichler, W., Gallart, F., Latron, J. 1999. Isotope hydrological study of mean transit times and related hydrogeological conditions in Pyrenean experimental basins. IAHS Publication 258, 101-110.

Klaus, J., McDonnell, J. 2013. Hydrograph separation using stable isotopes: Review and evaluation. Journal of Hydrology 505, 47-64. https://doi.org/10.1016/j.jhydrol.2013.09.006.

Latron, J. 2003. Estudio del funcionamiento hidrológico de una cuenca mediterránea de montaña (Vallcebre, Pirineos catalanes), Universitat de Barcelona, Unpublished $\mathrm{PhD}$ Thesis, Barcelona, $269 \mathrm{pp}$.

Latron, J., Gallart, F. 2007. Seasonal dynamics of runoff-contributing areas in a small Mediterranean research catchment (Vallcebre, Eastern Pyrenees). Journal of Hydrology 335 (1), 194-206. https://doi.org/10.1016/j.jhydrol.2006.11.012.

Latron, J., Gallart, F. 2008. Runoff generation processes in a small Mediterranean research catchment (Vallcebre, Eastern Pyrenees). Journal of Hydrology 358 (3), 206-220. https://doi. org/10.1016/j.jhydrol.2008.06.014.

Latron, J., Llorens, P., Gallart, F. 1997. Studying spatial and temporal patterns of runoff generation processes in a mountain Mediterranean basin (Vallcebre, Catalonia). Ecohydrological processes in small basins 14, 93-98.

Latron, J., Soler, M., Llorens, P., Gallart, F. 2008. Spatial and temporal variability of the hydrological response in a small Mediterranean research catchment (Vallcebre, Eastern Pyrenees). Hydrological Processes 22, 775-787. https://doi.org /10.1002/hyp.6648.

Latron, J., Llorens, P., Gallart, F. 2009. The hydrology of Mediterranean mountain areas. Geography Compass 3 (6), 2045-2064. https://doi.org/10.1111/j.1749-8198.2009.00287.x.

Latron, J., Soler, M., Llorens, P., Nord, G., Gallart, F. 2010. Hydrology in a Mediterranean mountain environment-the Vallcebre research basins (northeastern Spain). II. Rainfall runoff relationships and runoff processes. IAHS Publication 278, 151-156.

Latron, J., Roig-Planasdemunt, M., Llorens, P., Gallart, F. 2015. Combining stable isotopes and hydrometric data to investigate the stormflow response of a Mediterranean mountain catchment (Vallcebre Research Catchments, Spain), Geophysical Research Abstracts 17.

Levia, D.F., Frost, E.E. 2003. A review and evaluation of stemflow literature in the hydrologic and biogeochemical cycles of forested and agricultural ecosystems. Journal of Hydrology 274 (1): 1-29. https://doi.org/10.1016/S0022-1694(02)00399-2.

Levia, D.F., Germer, S. 2015. A review of stemflow generation dynamics and stemflowenvironment interactions in forests and shrublands. Reviews of Geophysics 53 (3), 673-714. https://doi.org/10.1002/2015RG000479.

Limousin, J.-M., Rambal, S., Ourcival, J.-M., Joffre, R. 2008. Modelling rainfall interception in a Mediterranean Quercus ilex ecosystem: lesson from a throughfall exclusion experiment. Journal of Hydrology 357 (1), 57-66. https://doi.org/10.1016/j.jhydrol.2008.05.001.

Llorens, P. 1997. Rainfall interception by a Pinus sylvestris forest patch overgrown in a Mediterranean mountainous abandoned area .II. Assessment of the applicability of Gash's analytical model. Journal of Hydrology 199 (3-4), 346-359. https://doi.org/10.1016/S00221694(96)03335-5.

Llorens, P., Gallart, F. 1994. Consecuencias hidrológicas de la reforestación de los campos abandonados: Diseño y resultados preliminares de un experimento en Cal Parisa (Vallcebre), Efectos geomorfológicos del abandono de tierras. Sociedad Española de Geomorfología, Instituto Pirenaico de Ecología, Institución Fernando el Católico, Zaragoza, pp. 95-105. 
Llorens, P., Latron, J., Gallart, F. 1992. Analysis of the role of agricultural abandoned terraces on the hydrology and sediment dynamics in a small mountainous basin (High Llobregat, Eastern Pyrenees). Pirineos 139, 27-46.

Llorens, P., Poch, R., Latron, J., Gallart, F. 1997. Rainfall interception by a Pinus sylvestris forest patch overgrown in a Mediterranean mountainous abandoned area .1. Monitoring design and results down to the event scale. Journal of Hydrology 199 (3-4), 331-345. https://doi. org/10.1016/S0022-1694(96)03334-3.

Llorens, P., Oliveras, I., Poyatos, R. 2003. Temporal variability of water fluxes in a Pinus sylvestris forest patch in Mediterranean mountain conditions (Vallcebre research catchments, Catalan Pyrenees). In: E. Servat, W. Najem, C. Leduc, A. Shakeel (Eds.), Hydrology of Mediterranean and Semiarid Regions. IAHS Publication 278, pp. 101-105.

Llorens, P., Poyatos, R., Delgado, J., Oliveras, I., Gallart, F. 2010. A multi-year study of rainfall and soil water controls on Scots pine transpiration under Mediterranean mountain conditions. Hydrological Processes 24 (21), 3053-3064. https://doi.org/10.1002/hyp.7720.

Llorens, P., Latron, J., Álvarez-Cobelas, M., Martínez-Vilalta, J., Moreno, G. 2011. Hydrology and biogeochemistry of mediterranean forests,. In: Forest Hydrology and Biogeochemistry. Springer, pp. 301-319. https://doi.org/10.1007/978-94-007-1363-5_14.

Llorens, P., Domingo, F., Garcia-Estringana, P., Muzylo, A., Gallart, F. 2014. Canopy wetness patterns in a Mediterranean deciduous stand. Journal of Hydrology 512, 254-262. https://doi. org/10.1016/j.jhydrol.2014.03.007.

Martínez-Carreras, N., Soler, M., Hernández, E., Gallart, F. 2007. Simulating badland erosion with KINEROS2 in a small Mediterranean mountain basin (Vallcebre, Eastern Pyrenees). Catena 71 (1), 145-154. https://doi.org/10.1016/j.catena.2006.05.013.

Martinez-Vilalta, J., Cochard, H., Mencuccini, M., Sterck, F., Herrero, A., Korhonen, J. F. J., Llorens, P., Nikinmaa, E., Nolè, A., Poyatos, R., Ripullone, F., Sass-Klaassen, U., Zweifel, R. 2009. Hydraulic adjustment of Scots pine across Europe. New Phytologist 184 (2), 353364. https://doi.org/10.1111/j.1469-8137.2009.02954.x.

Molina, A.J., Latron, J., Rubio, C.M., Gallart, F., Llorens, P. 2014. Spatio-temporal variability of soil water content on the local scale in a Mediterranean mountain area (Vallcebre, North Eastern Spain). How different spatio-temporal scales reflect mean soil water content. Journal of Hydrology 516, 182-192. https://doi.org/10.1016/j.jhydrol.2014.01.040.

Morán-López, T., Poyatos, R., Llorens, P., Sabaté, S. 2014. Effects of past growth trends and current water use strategies on Scots pine and pubescent oak drought sensitivity. European Journal of Forest Research 133 (2), 369-382. https://doi.org/10.1007/s10342013-0768-0.

Moreno-de las Heras, M., Gallart, F. 2016. Lithology controls the regional distribution and morphological diversity of montane Mediterranean badlands in the upper Llobregat basin (eastern Pyrenees). Geomorphology 273, 107-115. https://doi.org/10.1016/j. geomorph.2016.08.004.

Moreno de las Heras, M., Gallart, F., Latron, J., Martínez-Carreras, N., Ferrer, L., Estrany, J. 2017. Testing the use of $210 \mathrm{Pbex}$ to study sediment connectivity in a Mediterranean mountain basin with badlands. Land Degradation \& Development. https://doi.org/10.1002/ldr.2712.

Muzylo, A., Llorens, P., Valente, F., Keizer, J.J., Domingo, F., Gash, J.H.C. 2009. A review of rainfall interception modelling. Journal of Hydrology 370, 191-206. https://doi.org/10.1016/j. jhydrol.2009.02.058.

Mużyło, A., Llorens, P., Domingo, F. 2012a. Rainfall partitioning in a deciduous forest plot in leafed and leafless periods. Ecohydrology 5(6), 759-767. https://doi.org/10.1002/eco.266. 
Mużyło, A., Valente, F., Domingo, F., Llorens, P. 2012b. Modelling rainfall partitioning with sparse Gash and Rutter models in a downy oak stand in leafed and leafless periods. Hydrological Processes 26 (21), 3161-3173. https://doi.org/10.1002/hyp.8401.

Poyatos, R., Latron, J., Llorens, P. 2003. Land use and land cover change after agricultural abandonment - The case of a Mediterranean mountain area (Catalan Pre-Pyrenees). Mountain Research and Development 23 (4), 362-368. https://doi.org/10.1659/02764741(2003)023[0362:LUALCC]2.0.CO;2.

Poyatos, R., Llorens, P., Gallart, F. 2005. Transpiration of montane Pinus sylvestris L. and Quercus pubescens Willd. forest stands measured with sap flow sensors in NE Spain. Hydrology and Earth System Sciences 9 (5), 493-505. https://doi.org/10.5194/hess-9-493-2005.

Poyatos, R., Martínez-Vilalta, J., Cermák, J., Ceulemans, R., Granier, A., Irvine, J., Köstner, B., Lagergren, F., Meiresonne, L., Nadezhdina, N., Zimmermann, R., Llorens, P., Mencuccini, M. 2007. Plasticity in hydraulic architecture of Scots pine across Eurasia. Oecologia 153 (2), 245-259. https://doi.org/10.1007/s00442-007-0740-0.

Poyatos, R., Llorens, P., Pinol, J., Rubio, C. 2008. Response of Scots pine (Pinus sylvestris L.) and pubescent oak (Quercus pubescens Willd.) to soil and atmospheric water deficits under Mediterranean mountain climate. Annals of Forest Science 65 (3). https://doi.org/10.1051/ forest:2008003.

Regüés, D., Pardini, G., Gallart, F. 1995. Regolith behavior and physical-weathering of clayey mudrock as Dependent on seasonal weather conditions in a badland area at Vallcebre, Eastern Pyrenees. Catena 25 (1-4), 199-212. https://doi.org/10.1016/03418162(95)00010-P.

Regüés, D., Guàrdia, R., Gallart, F. 2000. Geomorphic agents versus vegetation spreading as causes of badland occurrence in a Mediterranean subhumid mountainous area. Catena 40 (2), 173-187. https://doi.org/10.1016/S0341-8162(99)00045-4.

Roig-Planasdemunt, M., Llorens, P., Latron, J. 2017. Seasonal and storm flow dynamics of dissolved organic carbon in a Mediterranean mountain catchment (Vallcebre, eastern Pyrenees). Hydrological Sciences Journal 62 (1), 50-63. http://doi.org/10.1080/02626667. 2016.1170942.

Roig-Planasdemunt, M., Latron, J., Llorens, P. Submitted. Spatial and temporal variability of depth to water table during rainfall-runoff events in a Mediterranean mountain catchment (Vallcebre, Eastern Pyrenees). Journal of Hydrology.

Rubio, C.M., Llorens, P., Gallart, F. 2008. Uncertainty and efficiency of pedotransfer functions for estimating water retention characteristics of soils. European Journal of Soil Science 59 (2), 339-347. https://doi.org/10.1111/j.1365-2389.2007.01002.x.

Solé, A., Gallart, F., Pardini, G., Aringhieri, R. 1992. How mudrock and soil physical properties influence badland formation at Vallcebre (Pre-Pyrenees, NE Spain). Catena 19 (3-4), $287-$ 300. https://doi.org/10.1016/0341-8162(92)90003-T.

Sterck, F.J., Martínez-Vilalta, J., Mencuccini, M., Cochard, H., Gerrits, P., Zweifel, R., Herrero, A., Korhonen, J.F.J., Llorens, P., Nikinmaa, E., Nolè, A., Poyatos, R., Ripullone, R., SassKlaassen, U. 2012. Understanding trait interactions and their impacts on growth in Scots pine branches across Europe. Functional Ecology 26 (2), 541-549. https://doi.org/10.1111/j.13652435.2012.01963.x.

Sus, O., Poyatos, R., Barba, J., Carvalhais, N., Llorens, P., Williams, M., Martínez-Vilalta, J. 2014. Time variable hydraulic parameters improve the performance of a mechanistic stand transpiration model. A case study of Mediterranean Scots pine sap flow data assimilation. Agricultural and Forest Meteorology 198, 168-180. https://doi.org/10.1016/j. agrformet.2014.08.009. 
Tetzlaff, D., Carey, S.K., McNamara, J.P., Laudon, H., Soulsby, C. 2017. The essential value of long-term experimental data for hydrology and water management. Water Resources Research 53 (4), 2598-2604. https://doi.org/10.1002/2017WR020838.

Valente, F., David, J., Gash, J. 1997. Modelling interception loss for two sparse eucalypt and pine forests in central Portugal using reformulated Rutter and Gash analytical models. Journal of Hydrology 190 (1-2), 141-162. https://doi.org/10.1016/S0022-1694(96)03066-1. 